\title{
The importance of context in understanding football fans' reactions to corporate stadia naming rights sponsorships
}

\section{Leah Gillooly}

Faculty of Business and Law, Manchester Metropolitan University, Manchester, UK

Dominic Medway and Gary Warnaby

Institute of Place Management, Manchester Metropolitan University, Manchester, UK, and

Tony Grimes

Sheffield Business School, Sheffield Hallam University, Sheffield, UK
Received 9 March 2018 Revised 1 October 2018 22 October 2019 Accepted 7 January 2020

\begin{abstract}
Purpose - The purpose of this paper is to explore fans' reactions to corporate naming rights sponsorship of football club stadia and identify a range of contextual factors impacting these reactions.

Design/methodology/approach - A qualitative, quasi-ethnographic research design is adopted, focusing on three football clubs in North West England. Data are gathered through online message board discussions, focus groups and auto-ethnographic approaches.

Findings - Geographic, image and functional dimensions of sponsorship fit are noted as contextual factors in determining fans' reactions to corporate stadium names. It is also proposed that some forms of fit (in particular geographic fit) are more important than others in this regard. Beyond issues of fit, three additional contextual factors are identified that potentially influence fans' reactions to corporate stadium names: prior involvement with the club by the sponsor; fans' perceived impact of the sponsorship investment; and whether the stadium is new or long-established.

Research limitations/implications - Future research might examine the relative importance and implications of the identified contextual factors, alongside seeking other potential areas of contextual framing.

Practical implications - Sponsorship naming rights negotiations need to be sensitive to a variety of contextual factors. Furthermore, sponsors would do well to have a good awareness of their own brand image and its congruency with the identity of the club and fan base.

Originality/value - This nuanced, qualitative analysis extends existing, quantitative-based research by identifying a range of contextual factors which shape fans' reactions to corporate stadium naming.
\end{abstract}

Keywords Sport, Sponsorship, Fans, Fit, Naming rights, Stadia

Paper type Research paper

(C) Leah Gillooly, Dominic Medway, Gary Warnaby and Tony Grimes. Published by Emerald Publishing Limited. This article is published under the Creative Commons Attribution (CC BY 4.0) licence. Anyone may reproduce, distribute, translate and create derivative works of this article (for both commercial and non-commercial purposes), subject to full attribution to the original publication and authors. The full terms of this licence may be seen at http://creativecommons.org/licences/by/4.0/ legalcode

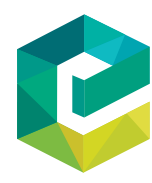

European Journal of Marketing Vol. 54 No. 7,2020 pp. $1501-1522$ Emerald Publishing Limited 0309-0566 DOI 10.1108/EJM-03-2018-0174 


\section{EJM}

54,7

1502

\section{Introduction}

The trading of stadia naming rights, or "selling home" (Boyd, 2000), has become a widespread aspect of sports sponsorship over the past 40 years. This practice differs from other sports sponsorships, typically relating to kits and events, which are examined extensively in the marketing literature (Bruhn and Holzer, 2015; Gwinner and Eaton, 1999; Grohs et al., 2015; Kwon et al., 2016; Madrigal, 2000; Nufer and Bühler, 2010; Roy and Cornwell, 2003). Specifically, stadia and their surroundings are places to which fans, and others, may feel strongly attached (Boyd, 2000; Reysen et al., 2012).

Such attachment was evident in the 2011 debacle over the renaming of Newcastle United Football Club's St James Park stadium, so named since 1880, to the "Sports Direct Arena". The club's owners argued that this change signalled the financial potential of Newcastle United to prospective sponsors and that the former name was no longer "commercially attractive" (BBC, 2011). In response, fans took direct action, painting the original name on the stadium's perimeter wall (BBC, 2012); and by 2013, the old name was reinstated (Edwards, 2012), suggesting that fan reactions to corporate stadium names are an important element in their potential as sponsorship vehicles.

Given the prevalence of corporate stadium (re)naming and the scale of investment, it continues to attract in football/soccer[1] and other sports/entertainment venues (Vuolteenaho et al., 2018). The practice remains an under-developed research area within the sponsorship literature, which to-date has taken a predominantly survey-based, quantitative approach (Nakazawa et al., 2016; Eddy, 2014; Woisetschläger et al., 2014; Reysen et al., 2012). In this regard, significant work has been carried out by Woisetschläger et al. (2014) in this journal, examining factors influencing fans' reactions to the corporate renaming of Borussia Dortmund's stadium. Existing studies emphasise a binary dimension of fan acceptance or resistance to stadium renaming. Resistance emanates from perceived threats of corporate stadium (re)naming to both club distinctiveness and fans' self-identity as followers of the club (Woisetschläger et al., 2014; Reysen et al., 2012). By contrast, a key factor influencing acceptance is the fit between sponsor and club (Woisetschläger et al., 2014).

These existing quantitative studies provide a critical contribution to understanding fan reactions to naming rights sponsorship. However, no two sponsorships (including naming rights) are necessarily the same, and all parties in the relationship (sponsor, rights holder, fans and other stakeholders) are able to contribute towards a range of contextual factors that combine to form unique sponsorship cases. Nonetheless, Reysen et al. (2012) note the lack of any detailed examination of how context might influence fans' reactions to corporate stadium re-naming. Addressing this lacuna serves as a central motivation for this study. The paper adopts a detailed, contrasting case-based (Stake, 2005) qualitative inquiry approach. In so doing, it adds a layer of complexity to existing quantitative work by shedding further insight on the importance of context in underpinning fans' reactions to naming rights sponsorship and the resulting explanations offered. The research is framed by one central research question: What are the contextual factors influencing fans' reactions to the corporate (re)naming of their team's football stadium?

In addressing this question, the paper develops two key contributions. Firstly, in line with previous studies, it is recognised that different dimensions of sponsorship fit can act as contextual factors in determining fans' reactions to corporate stadium names. However, building on this existing work, it is proposed that certain forms of fit and thereby certain aspects of context are more important than others in this regard. The second contribution proposes that there are additional and previously undocumented contextual factors beyond fit (both sponsored property related and sponsor related) that combine to shape fans' reactions to corporate stadium renaming. Overall, the research reveals that because 
contextual factors are so highly variable, there is no simple and replicable strategic marketing communications formula for the application and implementation of naming rights sponsorships in football or beyond.

The research is based on three English football clubs that have all undergone corporate stadium re-naming within the past 20 years. Two cases involve relocated and newly built stadia. However, the location of the third club's stadium has remained unchanged for over a century. The paper begins with a discussion of extant literature on corporate stadium (re)naming, before focusing on theoretical frameworks relating to sponsorship fit, gratitude and social identity theory, which have relevance to the interpretation of empirical data. The research approach is outlined, before findings are presented and discussed. The paper concludes by discussing theoretical contributions, managerial implications, limitations and areas for future research.

\section{Corporate stadium (re)naming}

As with other sponsorship contexts, an important motivation for corporate entities to engage in stadium (re)naming is brand awareness (Crompton and Howard, 2003), resulting from a greater number of brand name mentions, mostly via media reporting (Reysen et al., 2012). This can facilitate the sponsor's brand image enhancement (Roy and Cornwell, 1999), brand positioning (Hartland et al., 2005) and sales (Lough and Irwin, 2001). Occasionally, corporate stadium naming seems intertwined with corporate social responsibility (Plewa and Quester, 2011), particularly at a local level. Thus, where sponsors are perceived to have made a significant contribution to providing the local community with a new stadium, they are viewed more favourably (DeSchriver and Jensen, 2003). Previous work on corporate naming rights sponsorship has also examined its impact on variables including brand attitude, word-of-mouth intention (Woisetschläger et al., 2014) and purchase intention (Eddy, 2014).

Many empirical studies of corporate stadium renaming have focused on US college sports (Eddy, 2014; Reysen et al., 2012). Similar work in a European professional team sports context has tended to examine football; perhaps unsurprising given the game's popularity and the prevalence of corporate stadium naming in the sport (Vuolteenaho et al., 2018). In this context, studies of fan reactions to corporate stadium (re)naming have identified some negative outcomes, manifest in fans' hostility towards sponsors, refusal to use a stadium's new name (Woisetschläger et al., 2014), anger and perceived harm to the distinctiveness of the team (Reysen et al., 2012; Boyd, 2000). The Newcastle United example above illustrates how this can lead fans to demand that an original, non-corporate stadium name be reinstated. Such occurrences may create negative publicity, potentially causing the sponsor's brand more harm than good (Crompton, 2014). Alternatively, where fans believe the club benefits significantly from a naming rights agreement or where there is a strong perceived fit between naming sponsor and club, resistance is reduced (Woisetschläger $e t$ al., 2014).

Eddy (2014) suggests the naming rights landscape in US college sports is similar to that in many other sports worldwide, indicating that the actual sport itself does not have significant bearing on fan reactions to corporate stadium naming. What is perhaps more relevant here is context at a club level (Eddy, 2014), including factors such as differences in club financial security, which may influence reactions to corporate stadium renaming (Reysen et al., 2012). The between-club variability of such contextual factors proves problematic for generalising from existing quantitative studies and highlights the value of the qualitative approach adopted here in capturing rich and nuanced data on the phenomenon. A greater understanding of the contextual factors (and their interaction) that 
shapes fan reactions to stadium naming rights sponsorships should facilitate practitioner decision-making in this area (Chen and Zhang, 2011). One factor which has attracted considerable attention in previous work on sponsorship is the fit between club and sponsor.

\section{Sponsorship fit}

Fit has been conceptualised in terms of complementarity (Aaker and Keller, 1990) and the logic of a particular brand sponsoring a particular property (Olson and Thjømøe, 2011). Thus, fit might be broadly defined in terms of similarity, consistency, "making sense" (Simmons and Becker-Olsen, 2006) and a perceived logical connection between sponsor and sponsee (Speed and Thompson, 2000). Higher perceived levels of fit (or congruity) between sponsor and sponsored property can lead to more favourable attitudes towards naming rights sponsors (Chen and Zhang, 2011). Considerable empirical evidence exists to support the influence of fit on consumer responses to sponsorship (Petrovici et al., 2015; McDaniel, 1999), including sponsor identification (Johar and Pham, 1999), attitude towards the sponsor (Bruhn and Holzer, 2015; Gwinner and Bennett, 2008; Olson and Thjømøe, 2011; Weeks et al., 2008; Becker-Olsen and Hill, 2006; Rifon et al., 2004; Roy and Cornwell, 2003), attitude towards the sponsorship (Mazodier and Merunka, 2012; Simmons and Becker-Olsen, 2006), sponsor brand image (Grohs and Reisinger, 2014) and purchase intention (Speed and Thompson, 2000). Equally, perceived incongruity (or mis-fit) can harm evaluations of - and the equity attached to - both sponsor (Woisetschläger et al., 2010) and sponsored property (Groza et al., 2012). However, articulation of fit in formal announcements of naming rights sponsorships can aid positive brand attitude formation for incongruent sponsors (Skard and Thorbjornsen, 2017).

The literature on sponsorship fit is extensive (Olson and Thjømøe, 2011) with studies adopting different conceptualisations and measures of the fit construct (see Exhibit 1 in Olson and Thjømøe (2011) for an overview). Fit is frequently divided into either direct (functional/product related) fit or indirect (image based) fit (McDonald, 1991; Gwinner, 1997). Furthermore, Olson and Thjømøe (2011) suggest that overall fit may comprise elements of sponsor product relevance, attitude similarity, geographic similarity, audience similarity and sponsorship duration. It would thus appear that fit is multidimensional, comprising functional, geographic and image-based dimensions. These can be considered as bases of fit upon which fans might draw in articulating their reaction towards a corporate stadium name. Regardless of the dimensions included, sponsorship fit may be enhanced by prior attitude towards the sponsor (Nakazawa et al., 2016), perceived sponsor sincerity (Woisetschläger et al., 2010), sponsor's regional identification and perceived benefits (often financial) to the sponsored property (Woisetschläger and Haselhoff, 2009). This last aspect relates closely to notions of gratitude inherent in conceptualisations of sponsorship, often used to articulate fan acceptance of corporate money in sport.

\section{Sponsorship and gratitude}

Sponsorship has been contrasted with advertising in terms of goodwill (McDonald, 1991; Meenaghan, 1991, 2001), with the former received in a "halo of goodwill" generated by the perceived benefit accruing to the sponsored property, most notably at the individual sports club level (Meenaghan, 2001, p. 101). Here, goodwill is defined as "the positive attitude consumers convey toward a sponsor that supports and facilitates an event, team, or cause in which they are passionate" (Dees et al., 2008, p. 81). This differential response towards sponsorship (cf. advertising) has led scholars to suggest gratitude - defined as "the positive recognition of benefits received" (Emmons, 2004, p. 5) - as a sponsorship outcome (Kim et al., 2018). Gratitude is, therefore, deemed to include a sense of appreciation, goodwill and a 
resultant disposition to act positively towards the source (Fitzgerald, 1998). This urge to act through feelings of gratitude links with notions of reciprocity (Kim et al., 2018; Morales, 2005; Palmatier et al., 2009).

In the context of sports teams, feelings of gratitude can mediate the relationship between sponsorship and consumer outcomes, such as word-of-mouth and purchase intention (Kim et al., 2018; Kim et al., 2010). Feelings of gratitude might be driven by altruistic motives being attributed to the sponsorship, perceived value of the sponsorship received (Kim et al., 2018; Tsang, 2007) and perceived effort of the sponsor (Morales, 2005). The latter two can be seen as "investments" by corporate entities in achieving marketing outcomes. However, in a sports sponsorship context, Kim et al. (2018) found that perceived investment (as distinct from the perceived value/benefit to the recipient) did not have a significant impact on gratitude. There are also, arguably, first-mover advantages, with early sponsors engendering greater levels of gratitude than later, so-called, "bandwagon" sponsors (Meenaghan, 2001).

\section{Social identity theory}

Jones (2000, p. 283) identifies football fandom as a "serious leisure activity", where participation (or not) can be explained with reference to social identity theory (Tajfel, 1974). Social identity refers to

[.. . ] that part of an individual's self-concept which derives from his knowledge of his membership of a social group (or groups) together with the value and emotional significance attached to that membership (Tajfel, 1981, p. 255).

Further, social identity theory posits that people are motivated to enhance their self-concept (or self-esteem) by becoming members of social groups and making social comparisons that bolster the status of the "ingroup" (to which they belong) at the expense of the "outgroup" (Hogg and Abrams, 1988). This is particularly relevant with spectator sports, where fans are more likely to favour supporters of their own club, which they see as an extension of themselves, while criticising those from opposition clubs (Fink et al., 2009).

Any threat to the status of the ingroup (e.g. supporters of a particular club) is thus a threat to the self-esteem of its members. When individuals experience (or fear) negative evaluations of the ingroup, they are motivated to use identity maintenance strategies to protect their self-concept (Tajfel and Turner, 1979). These fall into three categories: social mobility, social creativity and social competition strategies (Doyle et al., 2017). Social mobility strategies include leaving the group or psychologically (and overtly) distancing oneself from it (e.g. by using detaching pronouns, such as "they" rather than "we" or not wearing apparel signalling group membership; Cialdini et al., 1976). Such actions are characterised as Cutting Off Reflected Failure (CORFing; Snyder et al., 1986) and regarded as realistic options only for those who do not identify strongly with the group (Fink et al., 2009). Social creativity strategies include downplaying the importance of the dimension(s) on which intergroup comparisons are made (e.g. sporting performance), shifting parameters to allow for more favourable ingroup evaluations (e.g. to the size and nature of support in the stadium) or changing the composition of the outgroup to facilitate more positive comparisons (Tajfel and Turner, 1979). Alternatively, members may seek to reframe negative evaluations as positive ingroup attributes (e.g. from "aggressive and hostile" to "strong and passionate"). They could also seek to protect their identity by re-categorising the entire group as belonging to a superior superordinate group or by identifying with a particular sub-group that is less inferior than other sub-groups (Blanz et al., 1998). Social competition strategies involve seeking to improve the relative standing of the ingroup by 
diminishing that of the outgroup, either physically through violence and intimidation or verbally via hostile criticism, ridicule or derogation of the outgroup - termed "blasting" by Cialdini and Richardson (1980).

A club's stadium arguably constitutes an important aspect of fan identity, representing not only an association to the club brand (Ross et al., 2006) but also part of the fan's extended self (Belk, 1988) and a place within which fans feel emotional and topophilic embeddedness (Edensor and Millington, 2008). As such, stadium renaming by a corporate sponsor could be a threat to ingroup distinctiveness (Eddy, 2014; Woisetschläger et al., 2014), to the point that it triggers identity maintenance strategies (Doyle et al., 2017) and concomitant resistance to that renaming (Woisetschläger et al., 2014; Reysen et al., 2012). Here, framing the corporate sponsor as an "outsider" to be resisted helps galvanise ingroup consistency. Other social creativity strategies (Doyle et al., 2017) can be used in response to corporate stadium sponsorship. For example, fans might reinforce positive aspects of the ingroup (Wann and Branscombe, 1995) by developing a shared positive reaction to their club's sponsors (Dalakas and Levin, 2005; Madrigal, 2000) and ultimately allowing for the sponsor to be included in the ingroup. Questions of whether, when and why football fans consider a stadium sponsor to be a threat to their self-concept, and which, if any identity maintenance strategies they used in response is clearly important and potentially complex. This suggests that social identity theory provides a useful lens through which to develop a deeper understanding of fan reactions to corporate stadium naming rights sponsorship.

\section{The clubs}

This study examines three football clubs, located in Greater Manchester, UK, which have changed their stadia names in the past $20+$ years to one associated with a corporate sponsor. One club, Bolton Wanderers, has (re)named its stadium three times in this period. The first instance coincided with a move from Burnden Park, where the club had played since 1895, to the newly built (and corporately named) Reebok Stadium in 1997, with a subsequent corporate renaming to Macron Stadium in 2014. Both Reebok and Macron are sportswear brands. In August 2018, the club announced a third renaming to the University of Bolton Stadium (Bolton Wanderers FC, 2018). This took place after the data collection phase of the study and was therefore not discussed by participants.

The second club, Manchester City, also represents an example of corporate naming of a newly built stadium, following relocation from Maine Road, where the team had played since 1923, to a new stadium in East Manchester in 2003 (originally built for the 2002 Commonwealth Games and then known as the City of Manchester Stadium). In 2011, the club agreed a deal with Manchester City Council (the stadium owners), securing control of naming rights in return for an increase in rent payments. A 10-year naming rights deal was subsequently signed with the airline operator Etihad (Taylor, 2011).

The final club, Oldham Athletic, has played at its current stadium since 1899. Until 2014, this stadium was called Boundary Park but was renamed SportsDirect.com Park following a five-year naming rights deal with this sportswear manufacturer/retailer (BBC, 2014). At the time of the research, these clubs played at different levels within the English professional football league structure: Manchester City in the Premier League (top tier), Bolton Wanderers in the Championship (second tier) and Oldham Athletic in League One (third tier).

\section{Method}

As noted above, previous studies of corporate stadium (re)naming in the sponsorship literature have used survey-based, quantitative approaches. However, this is not the most 
effective approach for gaining the rich and "thick" (Geertz, 1973) phenomenological insights from fans, befitting the current research question. Accordingly, this study's findings draw on various qualitative data sources resulting from a quasi-ethnographic research approach (Murtagh, 2007). Phase one involved engaging fans from Manchester City and Bolton Wanderers in online message board discussions on the (re)naming of their clubs' stadia, drawing on principles of netnography (Kozinets, 2015). Permission was sought, but not received, from Oldham Athletic fan message boards. Accordingly, the club was not included in this phase. The researchers identified themselves on message boards and clearly outlined the purpose of the research. Permission was requested to use data from message board participants and only quotes pertaining to such permissions being granted are presented below.

The second phase involved focus groups with fans of the three clubs, each involving between four and six participants, moderated by one or two of the authors. Focus groups lasted between 45 and 60 minutes and were based around a series of open-ended topic prompts informed by previous message board discussions. Thus, at the broadest level, questions covered issues such as like/dislike of relevant corporate stadium names and the reasons for this, and the relationship between corporate stadium names and financial investment in the club. Several club-specific prompts were included where relevant (e.g. the change of corporate names was discussed with Bolton fans). Focus group moderation guided discussions but allowed for diversion from topics in line with prevailing conversations. One focus group (Manchester City fans) took place at a nearby university, whereas the others were undertaken at pubs in Bolton and Oldham. As Oldham Athletic fans had not been included in the previous phase, two focus groups were held with them.

Recruitment of focus group participants used a combination of purposive and snowball sampling approaches (Bryman, 2004), as it was important to identify fans with a high level of attachment to the clubs, where the stadium (re)naming might be an issue of interest, or even concern. It was not, therefore, the intention to select focus group participants to be representative of all fan types, were this even possible (Bryman and Bell, 2011). Initial participant recruitment took place via advertisements posted on message boards and social media, through supporters' associations and from researchers' personal contacts. Those responding positively to participation in the study were then asked to recommend other fans who may wish to take part to widen the sample.

All focus group participants received a $£ 10$ Amazon gift certificate as a "thank you" for giving up their time. Participants ranged in age from 20 to 69, of which 14 were male and four female. This ratio is indicative of the recognised gender split in English football fans (EFL, 2015). Prior to their participation and to provide balance between transparency and the avoidance of priming effects, participants were instructed that the purpose was to understand fans' reactions to changes in the name of their club's stadium, including their associated thoughts, feelings and behaviours. All participants gave consent to include quotes in the publication of research findings. Table I provides an overview of participants for each focus group. No evidence was found for the effect of any demographic variables (e.g. gender, age) on responses given. All focus groups were transcribed and together with

\begin{tabular}{llll}
\hline Manchester City & Oldham Athletic (group 1) & Oldham Athletic (group 2) & Bolton Wanderers \\
\hline 4 males & 5 males & 3 males & 2 males \\
aged between 40 and 55 & aged between 20 and 69 & 2 females & 2 females \\
& & aged between 25 and 65 & aged between 25 and 69
\end{tabular}

Table I.

Focus group participants 
the downloaded transcripts of online message board threads, this amounted to 150 pages of text as a rich and multi-voiced fan discourse.

A third, auto-ethnographic phase involved two researchers attending matches at the three clubs to spend time among fans. On these occasions, the researchers also walked the immediate environs of the stadia to ascertain connections with current/former stadium names in the built urban fabric, e.g. in street names or local businesses. Observations were documented in field notes.

Following Abdallah and Langley (2014) and Heracleous (2006), analysis began from the position of viewing all data (message board posts, focus group transcripts and field notes) as text. Against the broad backdrop of the central research question [i.e. determining what contextual factors might influence fans' reactions to the corporate (re)naming of their team's football stadium], the researchers undertook an inductive and iterative form of thematic analysis (Braun and Clarke, 2006). This involved building up an initial set of themes after coding the message board data and then reorganising, revising and modifying them following the coding of focus group data and field notes. Emphasising a need for quality and reflexivity checks, the process was initially undertaken independently by each researcher. Subsequently, recognising the importance of confirmability in qualitative research (Lincoln and Guba, 1982), the authors met and collectively reviewed, negotiated and, where appropriate, merged their independent data interpretations. This allowed for further modification of key themes to emerge as part of a final, iterative negotiation step in the analysis. The findings emerging from this process are presented and discussed below.

\section{Contexts of sponsorship fit}

In explaining reactions towards particular naming rights sponsors, fans drew on a number of fit-based narratives, which appear intertwined with identity maintenance strategies. Although fans did not use the term "fit" in their explanations, notions of different bases of fit were clearly articulated, suggesting that the fit concept (however expressed) resonates with fans and is used in appraising naming rights sponsorships.

To understand fan conceptions of fit, it is helpful to start with a Bolton fan's statement that "'proper' stadium names would be either the location of the stadium - what road they're on or the district" (Bolton fan g), emphasising the importance of connections to the surrounding area. This logic seemingly extends to sponsors with local links, evidenced in Bolton fans' positive reactions to the former "Reebok" stadium name, a brand with origins in the town. Here, these "local" bases of fit were the first to be proposed by fans, suggesting that geographic fit is a starting point for fan acceptance of a naming rights sponsor. This is consistent with previous studies concerning the role and importance of geographic fit (Olson and Thjømøe, 2011; Woisetschläger et al., 2017). It reflects how English football clubs are deeply embedded in towns and cities (Edensor and Millington, 2008) with attempts to relocate them being met with fierce resistance, as exemplified by the case of Wimbledon FC's relocation to Milton Keynes (Goldblatt, 2014). Equally, football fandom is traditionally rooted in support for a local club, which can become a manifestation of fans' wider selfidentity as both fan of the club and resident and/or native of a particular town, city or region (Edensor and Millington, 2008; Giulianotti, 2002). Thus, narratives of geographic fit to articulate acceptance of naming rights sponsorships are indicative of wider social forces in English football, of which potential sponsors must be aware.

Between Etihad and Manchester City there was no obvious geographic fit, but fans were flexible in finding other forms of "symmetry" (Manchester City fan b) between sponsor and club to explain their acceptance. This included notions of congruency in values and image between these two entities: 
I like the fact that it was a new, up and coming company, the same as us. There's a whole new image for the club [...] We're going into the Champions League where, quite frankly, we're not really wanted. We're coming in as competitors to teams that have had it their own way for donkey's years and have looked down on us. And that was the impression I got about Etihad as well. They're suddenly coming into this market (Manchester City fan b).

Here, fit is apparently expressed in terms of a perceived degree of alignment between Etihad and the club, in terms of their similar organisational and competitive strategic positioning. With reference to social identity theory, this reflects a socially creative identity maintenance strategy, whereby club, fans and sponsor are categorised as belonging to a superordinate group (Blanz et al., 1998) of vibrant, anti-establishment interlopers or challengers. This suggests that, in the absence of geographic fit, fans' attitudes towards a stadium naming sponsor can arise from their understanding of its relative brand positioning within the market and thus its perceived identity (i.e. image fit).

The cases presented here indicate that fans use narratives of fit to articulate acceptance of corporate naming rights sponsors in a somewhat hierarchical manner, firstly seeking to explain acceptance based on geography. Where this is absent, fans sequentially broaden and increasingly abstract their appraisals to include image fit as a basis for acceptance. Although this shows how fit is an important contextual factor in determining fans' reactions to corporate stadium names, it also demonstrates their willingness to work hard to accept a corporate stadium name and be flexible in seeking bases of fit to support this decision. This suggests fans have a strong desire to find congruence between sponsee and sponsor (Simmons and Becker-Olsen, 2006) and to maintain the ingroup consistency associated with the social identity of being a loyal fan (Tajfel, 1982; Wann and Branscombe, 1995).

As well as employing narratives of image fit to explain acceptance of corporate stadium names, fans also draw on these narratives to articulate resistance (either actual or hypothetical) towards certain corporate stadium names. For example, citing the sportswear manufacturer and retailer Sports Direct, Bolton fans imagined a hypothetical scenario whereby functional fit would be cancelled out by a poor image compared to other potential sponsors:

I think it's different, isn't it [. . . I'm trying to give a good example [. . . I know Sports Direct is still sportswear but its association [...] [participant makes negative gesture]. Macron and Reebok are sportswear, you know, good sportswear so they still got good [...] I don't know, it's a positive brand, isn't it? (Bolton fan a).

These negative associations may be a reflection of fans' perceptions of Sports Direct as a low-quality sportswear brand or perhaps their understanding of its corporate social responsibility practices: at the time of data collection, a major news story surfaced about Sports Direct's "gulag"-like working conditions and poor contractual practices in the UK (Goodley and Ashby, 2015).

Fans also use strategies to reinforce a positive self/fan identity by openly expressing resistance towards perceived undesirable sponsors on an image/ethical level. One example was the highlighting of perceived unacceptable stadium names from other (not necessarily rival) clubs as well as hypothetical sponsor examples based on existing companies. These explanations were informed by fans' views of a sponsoring brand's relative market positioning, with suggestions that a bad stadium name is one linked to a brand perceived as representing cheapness or low value (i.e. poor image fit). Thus, it was suggested that Home Bargains, a UK-based discount retailer, would be "embarrassing" as a stadium name sponsor because "other fans would take the mickey" (Oldham fan h). Those fans openly criticising the perceived poor fit of corporate naming sponsors for other club stadia in this 
way are engaging in socially competitive identity maintenance strategies (Doyle et al., 2017), consciously or unconsciously presenting an outgroup for comparison as a way of rationalising the suitability of their own club's stadium naming arrangements. This is arguably an example of "blasting" (Cialdini and Richardson, 1980), with fans reinforcing the perceived fit of their team's naming rights sponsors through an "at least we're not as bad as [...]" narrative. Thus, by ridiculing another team's sponsors, fans protect their own ingroup identity.

Alongside sponsor brand image, fans apparently have difficulty in reconciling certain sponsor product categories with the image of their club and the resulting expression of their self-identity as a fan. In particular, there is resistance to the idea of payday loan providers as sponsors: "The danger is we'd have been called something like the Wonga Stadium [. . .] We wouldn't want to be associated with that" (Bolton fan c). The stigmatisation (Goffman, 1963) of this particular product category reflects the perceived negative impact such companies have on working class communities in which football is often ardently followed, an example, perhaps of poor image/ethical and geographic fit combined. As one Oldham Fan explained:

Anybody with intelligence would not go with Wonga [. . . Because it's a lower class area. I mean, there's higher-class areas and lower-class areas [...] So how do you expect the lower educated of Oldham to deal with things like that? They go, "Right, I need some money now, I'll get a loan. (Oldham fan a).

Here, resonating with Ruth and Simonin (2003), fans react negatively to perceived threats to the well-being of vulnerable people within their club's wider community.

Similar concerns were expressed regarding sponsors in the gambling sector, a subject that has attracted attention and debate in media, policy and academic spheres (BBC, 2016; Gambling Commission, 2014; Lamont et al., 2011). From a purely functional fit perspective, there is a clear product attribute connection (Smith, 2004) between gambling and sport, as sport accounts for approximately 13 per cent of the total global gambling market (Statista, 2017). However, most participants considered gambling a negative product category and gambling companies as undesirable sponsors:

It will happen sooner or later, you just hope you are not the first one [ . . ] a company like that [ . . ] a betting company, eventually it will get rights to a stadium and you don't want that (Bolton fan b).

Thus, fans appear to prioritise image/ethical fit over functional fit in determining reactions to particular corporate stadium names. When confronted with a potential sponsor whose perceived ethical record or stance does not match that desired of their club, the language of image fit is used as a narrative device to explain resistance. Thus, fans appear to have a threshold up to which they will use socially creative identity maintenance strategies, emphasising fit alignment between the sponsor and the club or even re-categorising both parties into a superordinate group based on shared or similar aspects of their image (Blanz et al., 1998). Conversely, if this threshold is breached, fans cast the sponsor as a threat to ingroup consistency (Tajfel, 1982), using alternative narratives of fit that disassociate their club and, by association, themselves from 'toxic' brands. Consequently, potential sponsors must be aware of the attributions fans make to particular product categories and the extent to which they are prepared to accept certain naming rights sponsors into their ingroup.

\section{Additional contextual factors influencing fan reactions}

Beyond issues of sponsorship fit, analysis reveals three additional contextual factors that potentially influence fans' reactions to corporate stadium names. These are prior 
involvement with the club by the corporate sponsor, fans' perceived impact of the sponsorship investment and whether the stadium is new or long established. In appraising the impact of these contextual factors, notions of gratitude appear exigent, alongside previously mentioned identity maintenance strategies.

\section{Prior involvement with the club}

A layer of contextual complexity is added to fans' reactions to corporate stadium renaming when taking into account previous involvement with the club. With Reebok (Bolton) and Etihad (Manchester City), for example, these brands first engaged in shirt sponsorship of the respective teams prior to signing stadium naming rights deals. Equally, both Manchester City and Etihad are owned by Abu Dhabi's ruling Al Nahyan family. Thus, it would appear that sponsors can ease the path to corporate stadium name acceptance by gradually escalating the scale of their involvement (sponsorship or otherwise), thereby demonstrating increasing commitment to the club. This process allows fans to reinforce the sponsor's positive aspects as a member of the ingroup (Wann and Branscombe, 1995) based on synergy and even oneness with the club, rather than using identity maintenance strategies involving disassociation and resistance:

I think it's also a positive that Etihad as a sponsor is now so inextricably linked with the club [...] Perhaps no other company in our history has been so closely linked to the club [...]. It's a brand that I associate with the City takeover and our recent resurgence as one of the most successful clubs in England. The company increasing their sponsorship to include the stadium and campus only further emphasises my positive view of the brand (Manchester City fan $\mathrm{p}$ ).

This echoes aspects of commitment and consistency theory (Cialdini, 2009). Thus, fans who had previously accepted, and even welcomed, the involvement of a corporate entity with their club (e.g. as a shirt sponsor, major investor or owner), are inclined to remain consistent with this position when evaluating the appropriateness of that same company, or one in the same broad product category, as a stadium naming rights sponsor.

Evidence from beyond this study also suggests that a sponsor's prior involvement with the club might even help offset fan concerns about image/ethical fit discussed above, specifically in terms of perceived negative sponsor product categories, such as gambling. For example, shortly after data collection took place, an announcement was made that the stadium of Stoke City Football Club (a Premier League team) would be renamed after the gambling brand Bet365 (De Menezes, 2016). Based on the insights from fans in this study, it might be expected that such a deal would elicit significant resistance, yet this did not occur. Rather, this naming rights deal was reported in the press as strengthening the sponsor's association with the club, reflecting the fact that the owners of Bet365 also own Stoke City, and that Bet365 was already the club's shirt sponsor (De Menezes, 2016). Here, it seems prior involvement with the club by Bet365 helped ameliorate any negative associations that fans might hold of gambling brands as naming rights sponsors. Specifically, the stance fans adopt with regard to a corporate sponsor may be affected by positions they have previously assumed towards that same organisation in its relationships with their club. This illustrates not only the influence of contextual factors on fan reactions to corporate stadium naming but also how this can vary between cases; something sponsors must be cognisant of when considering pursuing stadium naming rights deals.

\section{Perceived impact of sponsorship investment}

Prominent in all discussions with fans, both on message boards and in focus groups, was the issue of money. Although certain brands and product categories are perceived as carrying 
negative connotations as potential stadium names, when faced with the reality of a sponsoring brand with a potentially problematic image, fans also deploy counter discourses, espousing a desire to distance themselves from the corporate naming rights sponsor, but appreciating the importance of the financial investment. These typically trade-off the corporate stadium name with the financial benefits accruing to the club:

I would prefer not to be associated with a business like Sports Direct. But like people have said, if they give you the money, then you take the money. (Oldham fan i)

This suggests that fans can, to some extent, rationalise acceptance of a naming rights sponsor with a poor image if the financial rewards are significant enough. One Manchester City fan emphasised this pragmatic approach by fans to the contemporary commercial realities of football:

[... .] whatever it takes to get that money, do it. I'd even accept a crap name. I wouldn't like it. Don't get me wrong. I wouldn't like it. But if it was enough money involved, I'd accept anything [... . . It's the way football is. You need that money (Manchester City fan b).

This echoes Woisetschläger et al. (2014) who suggest that the benefits received through sponsorship can mitigate resistance to corporate stadium naming. The perceived financial impact of the naming rights sponsorship thus emerges as a powerful contextual factor, which in this study, manifests itself in contrasting ways depending on what is at stake for fans.

What fans consider to be a fair financial return for the naming rights to a stadium apparently differs in scale according to the current resources of their club: "you'd need to know that naming it Macron or whatever has made a significant impact to your club" (Bolton fan a). The phrase, "significant impact" was referred to frequently by fans of all three clubs as constituting the ability to buy (and pay wages for) players. This supports findings that team performance is the most salient dimension used by fans when comparing themselves to other clubs (End et al., 2002). Where fans felt that sponsorship money received was insufficient to facilitate such player purchases, or might only cover the wages of perceived inferior players, willingness to accept a corporate stadium name receded.

Building upon the assertion that fans wish to protect their self-identity from threats presented by sponsorship from negatively viewed brands/products, further nuance is added if that sponsorship can ensure the club's survival or at the very least prevent its relegation to a lower league. Club survival could be viewed as the ultimate fair return for stadium naming rights, even if the name involved constitutes a potential threat to fans' self-identity in other ways, because without the club any nexus of fans' identity formation is lost. The fact that Oldham is a club struggling for financial survival (Frost, 2017) illustrates this with sponsorship monies from Sports Direct perceived to "keep [the] club going" (Oldham fan d) in a context where rumours were "going around that the players haven't been paid" (Oldham fan j):

To be quite honest with you, they can change [...]. Boundary Park every year for the next 10 years and give us a million pounds for it and I'll be over the moon [ . . ], because that will keep my club going, that. That's all I'm bothered about. (Oldham fan d)

It is therefore suggested that fans will prioritise team survival as the ultimate identity consideration, leading them to justify acceptance of corporate stadium renaming where they perceive the benefit to be worth the financial trade-off.

However, where fans' overriding desire to ensure club survival is facilitated by money from a source they perceive to be in some way undesirable, the commitment displayed towards the sponsor is tempered with a degree of reluctant acceptance. Thus, whilst Oldham 
fan $\mathrm{f}$ articulated his appreciation of the sponsorship money ("Initially, I didn't like it. But then, as soon as I saw the money involved; thank you, from me personally"), there was no evidence that this reflected genuine gratitude and a willingness or obligation to reciprocate. Indeed, when asked directly whether the naming rights sponsorship would affect their purchase behaviour towards the sponsor brand's products, Oldham fans declared it would make "no difference" (Oldham fan e). They were happy to accept the corporate sponsorship money, but with no reciprocal obligation in terms of their attitudes towards or patronage of the sponsor brand.

By contrast, Manchester City fans displayed a willingness to use the corporate stadium name, demonstrating greater gratitude for monies received: "If they're going to back us with money, the least I can do is back them” (Manchester City fan b). In fact, fans' gratitude included reciprocal commitment by making a conscious, active effort to consider the Etihad brand when making purchase decisions. A distinction can be drawn between the outcomes of the financial investment through naming rights sponsorship for Manchester City and Oldham. With the former, the scale of the investment has facilitated a significant upturn in team performance, allowing the club to invest in superstar players who have propelled the club to success in league and cup competitions:

Nowadays, I always call it the Etihad because finance has become crucial to our development on the pitch. If a sponsor is willing to financially support the club, I'm happy to publicise their name (Manchester City fan b).

Therefore, the sponsorship investment at Manchester City is regarded by fans as facilitating success. This, combined with the positive image fans have of the sponsor, leads them to display their gratitude, manifest in a willingness to endorse, promote and, in some cases, use the Etihad brand.

Unlike Manchester City, sponsorship investment at Oldham does not seem to facilitate on-pitch success, merely club survival. Where acceptance of sponsorship money is seen more as a trade-off in which the benefit to the club outweighs the negative associations of the sponsor brand, fans appear to demonstrate less allegiance to the naming partner. Thus, Oldham fans continue to use the Boundary Park stadium name in everyday discourse and claim no elevated purchase intentions towards SportDirect.com as the sponsor brand. Hence, this naming rights deal was variously referred to by Oldham fans as "money for old rope" (Oldham fan b) or "free money" (Oldham fan g).

Considering Fitzgerald's (1998) definition of gratitude as comprising appreciation, a sense of goodwill and a resultant disposition to act, the findings relating to Manchester City support the contention that gratitude may be driven by the perceived value of the sponsorship (Kim et al., 2018; Tsang, 2007). However, in cases where fans might hold more negative associations of the naming rights sponsor, as with Oldham, they are likely to show reluctant acceptance of the money, with no real conversion of this into gratitude or feeling the necessity to reciprocate - perhaps because the negative image of the sponsoring company makes it unworthy of such action.

\section{New vs established stadia}

The cases examined in this paper represent examples of corporate naming rights sponsorship for newly built (Bolton and Manchester City) and long-established (Oldham) stadia. Differences in fan reactions to corporate stadium renaming for newly built versus long-established stadia have been well-documented (Medway et al., 2018; Crompton and Howard, 2003). Medway et al. (2018) discuss how fans are generally accepting of corporate names for newly built stadia not imbued with an existing name and which have not yet 
acquired the status of "memory places" (Boyd, 2000), where fans fondly remember past footballing triumphs and experiences. This helps explain results from Vuolteenaho's et al.'s (2018) study of 193 European football clubs, showing a higher percentage of sponsor-named stadia for post-1990 venues (59.2 per cent) than for older facilities. Similarly, for Bolton and Manchester City, fans' general acceptance of the corporate names for their current stadia was - at least partially - explained by the fact that both clubs had relocated to these in recent times:

I have no issues with the naming of the stadium after a sponsor as there is very little 'history' here (Manchester City fan e).

To be honest, I didn't mind because it was a totally new stadium (Bolton fan c).

However, evidence suggests there are additional complexities to consider in terms of fans' real and imagined reactions to corporate stadium (re)naming and the wider context of stadium longevity.

For example, both Manchester City and Bolton fans contrasted the acceptance of corporate naming rights sponsors for their current newly-built stadia with a hypothetical resistance to the renaming of former long-established stadia:

I would have been passionately opposed to Maine Rd being rebranded. It had a history and an identity that is extremely important to fans. A rebranding just would not have worked, much like it didn't as St James's Park [Newcastle United's stadium], for the same reasons [... ]. You simply cannot rebrand a stadium which has had a name for 100 years, people are too attached to it (Manchester City fan p).

I would have been totally disgusted [had they renamed Burnden Park]. I don't think I could have accepted that (Bolton fan c).

Yet even within this hypothetical realm, there was no indication from these fans that they would have engaged in CORFing (Snyder et al., 1986) or social mobility-based strategies for identity maintenance (Doyle et al., 2017), such as withdrawing their support for the club or switching allegiance to another. It appears, therefore, that such hypothesising allows fans to feel as though they are reasserting some power against any perceived overcommercialisation of football, permitting them to enact a form of "safe" resistance (albeit attitudinally), free of any negative financial or image-related consequences for their club.

Significantly, with both Bolton and Manchester City, the survival of neither club was particularly at risk at the time of data collection, and thus fans were not faced with a wider existential threat to their identities as fans. This was not the case for Oldham, where the club was in a precarious financial state, as discussed earlier. This may help to explain why Oldham fans, who had witnessed the corporate renaming of their long-established stadium, were keen to use social creativity strategies, selecting club survival as the primary basis for their identity maintenance, and thereby a means to justify their reluctant acceptance of the corporate name.

\section{Conclusion}

This paper set out with one central research question, namely, to determine the contextual factors influencing fans' reactions to the corporate (re)naming of their team's football stadium.

The findings indicate that fans articulate such reactions in terms of various dimensions of sponsorship fit, which contribute towards the maintenance of their self-identity. This 
aligns with the work of others, such as Woisetschläger et al. (2014). Adding to this work, it is also proposed that fans prioritise some forms of fit over others, with geographical connections between corporate naming sponsor and club being particularly salient in allowing fans to maintain an ingroup consistency and self-identity position that supports naming rights acceptance. Where these geographical connections are absent, fans appear to seek out other forms of fit relating to alignment between the values and image of the corporate naming sponsor and their club, which can also facilitate acceptance of a corporate stadium name; this reflects a socially creative identity maintenance strategy. Functional fit is also recognised by fans but appears to be overridden by image fit. In sum, both the different types of sponsorship fit, and then how those might be prioritised, emerge within this paper as important contextual factors in shaping fans' reactions to corporate stadium (re)naming. This represents the first key contribution of this study.

A second contribution is the surfacing of three additional contextual factors that may further influence fans' reactions to the corporate (re)naming of their team's football stadium. The first of these is prior involvement with a club by a sponsor. Critical to this is visible evidence or knowledge among the fan base of a sponsor's previous substantive commitment to their club. This appears to influence reactions to a corporate stadium name by reinforcing the perceived positive aspects of fit between the sponsor and football club as sponsee, and mitigating any apparent negative aspects.

Another additional contextual factor relates to the perceived impact of sponsorship investment on a club's fortunes, whereby an apparent positive impact appears to make fans more likely to rationalise or overlook aspects of poor fit that might easily threaten their selfidentity. Put simply, larger and more lucrative stadium naming rights deals may be more likely to reduce resistance to naming rights sponsorships that have perceived poor fit with the club. Furthermore, fans' perceptions of what is "fair financial return" from a stadium naming rights deal may vary according to the club's financial resources, with the bar being set far lower in this regard for cash-poor clubs, as is evident from the views of Oldham Athletic fans above.

An additional point here relates to how fans' perceived impact of sponsorship monies from naming rights deals interacts with notions of sponsor image fit. Where such sponsorship investment is perceived to facilitate on-pitch success and comes from a sponsor with a perceived positive image, fans appear to display genuine gratitude towards that sponsor, as was seen in the case of Manchester City fans who spoke of a greater willingness to purchase Etihad products. In contrast, where the naming rights sponsor has a perceived negative image, and where that sponsor's investment can only preserve but not necessarily enhance the club's performance and status, fans can display a more reluctant acceptance of the sponsorship and the associated stadium name. This was the case with Oldham Athletic fans, who showed little reciprocal purchase intention (and thus, little true gratitude) towards SportsDirect.com as a corporate naming rights sponsor.

A third additional contextual factor influencing fans' reactions to the corporate stadium (re)naming relates to newly built versus established stadia. Specifically, findings here support existing research (Vuolteenaho et al., 2018), suggesting that established stadia are always likely to be a more troublesome target for naming rights deals and consequently less likely to deliver a full range of positive outcomes for the sponsor. This is due to their status as "memory places" (Boyd, 2000) for fans. However, if a club with a long-established stadium is in a precarious financial state, then corporate renaming of the stadium may become more viable if it can deliver a perceived fair financial return that can ultimately preserve rather than threaten fans' identity by ensuring club survival. This was the case with Oldham Athletic, where the renaming of Boundary Park to SportsDirect.com Park was 
accepted - albeit reluctantly and without true gratitude towards the sponsor - due to the parlous state of the club's finances.

Furthermore, no two sponsorships or clubs will necessarily display identical combinations of contextual factors, meaning fan reactions to stadium naming rights deals may vary accordingly. On the one hand, this makes it more difficult to predict fan reactions to any given stadium naming rights deal. However, consistent with Firestone's (1993) concept of case-to-case translation as a form of generalisability, the detailed descriptions of the cases presented will permit an evaluation of the extent to which identified combinations of contextual factors are present in other cases or situations (Polit and Beck, 2010), both within and outwith football. Nonetheless, the evident variability of contextual factors for the cases discussed in this paper suggest that the strategic marketing communications formula for naming rights sponsorships in football, and indeed sport more generally, cannot simply be replicated.

\section{Managerial implications}

In terms of its managerial implications, this study identifies that sponsorship naming rights negotiations need to be sensitive to the variety of contextual factors relating to local club conditions, including a club's financial state, sporting performance and the age of the stadium. Moreover, prior investment by the sponsor can smooth the way to fan acceptance of a naming rights sponsorship deal. This points to potential naming rights sponsors starting with smaller sponsorship assets (e.g. pitchside hoardings and shirts) to weave the sponsor's presence into fans' quotidian understandings and discourses. Such an approach allows the sponsor to demonstrate commitment and build familiarity, trust and credibility with a club's fan base, before embarking on a significant stadium renaming deal. Sponsors should also be ready to scale-up their investment in a naming rights deal in line with higher club performance to deliver notions of "fair financial return". In addition, it would appear evident that naming rights sponsors would do well to have a good awareness of their own brand image and its congruency with the existing identity of the club and fan base.

\section{Limitations and areas for future research}

This study has examined how various contextual factors might influence fans' reactions to corporate stadium (re)naming, focusing on three football clubs based in the North West of England, all of which are contextually unique. Future research could seek to identify other forms of contextual framing affecting fans' reactions to naming rights sponsorship deals, arising in, for example, the relative league position of football clubs or the landscape of professional football and associated fan bases in other countries. Another contextual focus for future research is to examine how fan reactions to stadium naming rights alter over time with the inevitable turnover of corporate sponsors. Specifically, as we move into the second, and sometimes third, generation of corporate naming sponsors for football stadia (as in the case of Bolton), there is more work to be done in examining how the fans' reactions to an existing corporate naming deal for their club's stadium might be affected (negatively or positively) by the perceived success of previous naming rights sponsorships. Examination of the contextual factors influencing fans' reactions to corporate stadium names in other sports, beyond football, is also an area of future potential research interest. Such studies could usefully build on the theoretical contributions and managerial implications from this paper to help inform naming rights sponsorship decision-making.

Further building on the above research, another line of future potential enquiry could involve trying to determine the relative importance or weighting of those different contextual factors identified as influencing fan reactions to corporate stadium naming rights 
sponsors. For example, is there a relative threshold of fair financial return on naming rights investment, above which fans are prepared to trade off additional sponsorship income for higher levels of perceived fit? In addition, in the above findings fan narratives of gratitude towards sponsors have been explored, highlighting differences between genuine gratitude, characterised by notions of reciprocity and more reluctant acceptance, with no contingent impact on purchase intention of the sponsor brand or club-related goods and services. Field studies using sales data might helpfully contribute to further advancing this perspective on differing fan reactions to corporate naming rights sponsors and to sports clubs as recipients of sponsorship monies. In relation to the latter, for example, could reluctant acceptance of naming rights sponsorship have consequences for the club in terms of fans' match-day practices - e.g. fans' behaviour in the stands or their pre- and post-match dwell time and associated additional spending within the stadium?

This study predominantly explored the views of "local" fans (although the message board phase of the research did allow for participation from a more geographically dispersed fan base). Therefore, future research might look to examine differences in reactions to corporate stadium (re)naming between local and more dispersed fan bases. For example, as professional sports become increasingly global in their reach, will fan reactions and the narratives used shift away from notions of geography and, as such, should sponsors focus on identifying and cementing alternative bases of fit to facilitate acceptance?

\section{Note}

1. The term "football" is subsequently used throughout this paper, privileging the voice of the fans studied. However, it is recognised this could be substituted for "soccer" in a North American context.

\section{References}

Aaker, D.A. and Keller, K.L. (1990), "Consumer evaluations of brand extensions”, Journal of Marketing, Vol. 54 No. 1, pp. $27-41$.

Abdallah, C. and Langley, A. (2014), "The double edge of ambiguity in strategic planning”, Journal of Management Studies, Vol. 51 No. 2, pp. 235-264.

BBC (2011), "Newcastle rename St James' park the sports direct arena”, available at: www.bbc.co.uk/ sport/football/15668207 (accessed 21 April 2016).

BBC (2012), "St James' park graffiti: Michael Atkinson admits painting stadium", available at: www. bbc.co.uk/news/uk-england-tyne-17077966 (accessed 1 February 2018).

BBC (2014), "Oldham athletic: boundary park to become SportsDirect.com park", available at: www. bbc.co.uk/sport/football/28144525 (accessed 23 February 2017).

BBC (2016), "Gambling ads criticised on first day of Australian open", available at: www.bbc.co.uk/ news/world-australia-35259767 (accessed 10 March 2017).

Becker-Olsen, K.L. and Hill, R.P. (2006), "The impact of sponsor fit on brand equity: the case of nonprofit service providers", Journal of Service Research, Vol. 9 No. 1, pp. 73-83.

Belk, R.W. (1988), "Possessions and the extended self", Journal of Consumer Research, Vol. 15 No. 2, pp. 139-168.

Blanz, M., Mummendey, A., Mielke, R. and Klink, A. (1998), "Responding to negative social identity: a taxonomy of identity management strategies", European Journal of Social Psychology, Vol. 28 No. 5, pp. 697-729. 
Bolton Wanderers FC (2018), "Welcome to the university of bolton stadium", available at: www.bwfc. co.uk/news/2018/august/welcome-to-the-university-of-bolton-stadium/ (accessed 28 August 2018).

Boyd, J. (2000), "Selling home: Corporate stadium names and the destruction of commemoration", Journal of Applied Communication Research, Vol. 28 No. 4, pp. 330-346.

Braun, V. and Clarke, V. (2006), "Using thematic analysis in psychology", Qualitative Research in Psychology, Vol. 3 No. 2, pp. 77-101.

Bruhn, M. and Holzer, M. (2015), "The role of the fit construct and sponsorship portfolio size for event sponsorship success: a field study", European Journal of Marketing, Vol. 49 Nos 5/6, pp. 874-893.

Bryman, A. (2004), Social Research Methods, 2nd ed., Oxford University Press, Oxford.

Bryman, A. and Bell, E. (2011), Business Research Methods, 3rd ed., Oxford University Press, Oxford.

Chen, K.K. and Zhang, J.J. (2011), "Examining consumer attributes associated with collegiate athletic facility naming rights sponsorship: development of a theoretical framework", Sport Management Review, Vol. 14 No. 2, pp. 103-116.

Cialdini, R.B. (2009), Influence: Science and Practice, 5th ed., Pearson Education, Boston, MA.

Cialdini, R.B. and Richardson, K.D. (1980), "Two indirect tactics of image management: basking and blasting", Journal of Personality and Social Psychology, Vol. 39 No. 3, pp. 406-415.

Cialdini, R.B., Borden, R.J., Thorne, A., Walker, M.R., Freeman, S. and Sloan, L.R. (1976), "Basking in reflected glory: three (football) field studies”, Journal of Personality and Social Psychology, Vol. 34 No. 3, pp. 366-375.

Crompton, J.L. (2014), "Potential negative outcomes from sponsorship for a sport property", Managing Leisure, Vol. 9 No. 6, pp. 420-441.

Crompton, J.L. and Howard, D.R. (2003), "The American experience with facility naming rights: opportunities for English professional football teams", Managing Leisure, Vol. 8 No. 4, pp. 212-226.

Dalakas, V. and Levin, A.M. (2005), "The balance theory domino: How sponsorships may elicit negative consumer attitudes", in Menon, G. and Rao, A.R. (Eds), NA - Advances in Consumer Research Volume, 32, Association for Consumer Research, Duluth, MN, pp. 91-97.

De Menezes, J. (2016), "Stoke city to rename Britannia the bet365 stadium after reaching deal to expand capacity beyond 30,000 mark", The Independent, available at: www.independent.co.uk/sport/ football/premier-league/stoke-city-to-rename-britannia-the-bet365-stadium-after-reaching-deal-toexpand-capacity-beyond-a6994626.html (accessed 26 July 2018).

Dees, W., Bennett, G. and Villegas, J. (2008), "Measuring the effectiveness of sponsorship of an elite intercollegiate football program", Sport Marketing Quarterly, Vol. 17 No. 2, pp.79-89.

DeSchriver, T.D. and Jensen, P.E. (2003), "What's in a name? Price variation in sport facility naming rights”, Eastern Economic Journal, Vol. 29 No. 3, pp. 359-376.

Doyle, J.P., Lock, D., Funk, D.C., Filo, K. and McDonald, H. (2017), “I was there from the start': the identity-maintenance strategies used by fans to combat the threat of losing", Sport Management Review, Vol. 20 No. 2, pp. 184-197.

Eddy, T. (2014), "Measuring effects of naming-rights sponsorships on college football fans' purchasing intentions", Sport Management Review, Vol. 17 No. 3, pp. 362-375.

Edensor, T. and Millington, S. (2008), "This is our city': branding football and local embeddedness", Global Networks, Vol. 8 No. 2, pp. 172-193.

Edwards, L. (2012), "Newcastle united sponsorship deal with wonga will see St James' park reinstated as stadium name", The Telegraph, available at: www.telegraph.co.uk/sport/football/teams/ newcastle-united/9596399/Newcastle-United-sponsorship-deal-with-Wonga-will-see-St-James-Parkreinstated-as-stadium-name.html (accessed 21 April 2016).

EFL (2015), "Infographic: 2015 fan survey”, available at: www.efl.com/news/article/2015/infographic2015-fan-survey-2784954.aspx (accessed 27 February 2017). 
Emmons, R.A. (2004), "The psychology of gratitude: an introduction", in Emmons, R.A and McCullough, M.E. (Eds), The Psychology of Gratitude, Oxford University Press, New York, NY, pp. 3-16.

End, C.M., Dietz-Uhler, B., Harrick, E.A. and Jacquemotte, L. (2002), "Identifying with winners: a reexamination of sport fans' tendency to birg", Journal of Applied Social Psychology, Vol. 32 No. 5, pp. 1017-1030.

Fink, J.S., Parker, H.M., Brett, M. and Higgins, J. (2009), "Off-field behavior of athletes and team identification: using social identity theory and balance theory to explain fan reactions", Journal of Sport Management, Vol. 23 No. 2, pp. 142-155.

Firestone, W.A. (1993), "Alternative arguments for generalizing from data as applied to qualitative research”, Educational Researcher, Vol. 22 No. 4, pp. 16-23.

Fitzgerald, P. (1998), “Gratitude and justice”, Ethics, Vol. 109 No. 1, pp. 119-153.

Frost, R. (2017), "Oldham athletic challenge winding-up petition brought by HMRC", available at: www. insidermedia.com/insider/northwest/oldham-athletic-challenge-winding-up-petition (accessed 13 September 2017).

Gambling Commission (2014), "Sponsorship of British sporting clubs by gambling operators", available at: www.gamblingcommission.gov.uk/PDF/Sponsorship-of-British-sporting-clubs-bygambling-operators.pdf (accessed 10 March 2017).

Geertz, C. (1973), The Interpretation of Cultures, Basic Books, New York, NY.

Giulianotti, R. (2002), "Supporters, followers, fans, and flâneurs: a taxonomy of spectator identities in football", Journal of Sport and Social Issues, Vol. 26 No. 1, pp. 25-46.

Goffman, E. (1963), Stigma: Notes on the Management of Spoiled Identity, Prentice-Hall, Englewood Cliffs, NJ.

Goldblatt, D. (2014), The Game of Our Lives: The Meaning and Making of English Football, Penguin.

Goodley, S. and Ashby, J. (2015), "A day at 'the gulag': what it's like to work at sports direct's warehouse", The Guardian, available at: www.theguardian.com/business/2015/dec/09/sportsdirect-warehouse-work-conditions (accessed 22 June 2017).

Grohs, R. and Reisinger, H. (2014), "Sponsorship effects on brand image: the role of exposure and activity involvement", Journal of Business Research, Vol. 67 No. 5, pp. 1018-1025.

Grohs, R., Reisinger, H. and Woisetschläger, D.M. (2015), "Attenuation of negative sponsorship effects in the context of rival sports teams' fans”, European Journal of Marketing, Vol. 49 Nos 11/12, pp. 1880-1901.

Groza, M.D., Cobbs, J. and Schaefers, T. (2012), "Managing a sponsored brand: the importance of sponsorship portfolio congruence", International Journal of Advertising, Vol. 31 No. 1, pp. 63-84.

Gwinner, K. (1997), “A model of image creation and image transfer in event sponsorship”, International Marketing Review, Vol. 14 No. 3, pp. 145-158.

Gwinner, K. and Bennett, G. (2008), "The impact of brand cohesiveness and sport identification on brand fit in a sponsorship context", Journal of Sport Management, Vol. 22 No. 4, pp. 410-426.

Gwinner, K.P. and Eaton, J. (1999), "Building brand image through event sponsorship: the role of image transfer", Journal of Advertising, Vol. 28 No. 4, pp. 47-57.

Hartland, T., Skinner, H. and Griffiths, A. (2005), "Tries and conversions: are sports sponsors pursuing the right objectives?”, International Journal of Sports Marketing and Sponsorship, Vol. 6 No. 3, pp. 20-29.

Heracleous, L. (2006), "Discourse, interpretation", Organization, Cambridge University Press, Cambridge.

Hogg, M.A. and Abrams, D. (1988), Social Identifications: A Social Psychology of Intergroup Relations and Group Processes, Routledge, London. 
Johar, G.V. and Pham, M.T. (1999), "Relatedness, prominence, and constructive sponsor identification", Journal of Marketing Research, Vol. 36 No. 3, pp. 299-313.

Jones, I. (2000), “A model of serious leisure identification: the case of football fandom”, Leisure Studies, Vol. 19 No. 4, pp. 283-298.

Kim, Y.K., Smith, R. and James, J.D. (2010), "The role of gratitude in sponsorship: the case of participant sports", International Journal of Sports Marketing and Sponsorship, Vol. 12 No. 1, pp. 48-70.

Kim, Y., Smith, R.D. and Kwak, D.H. (2018), "Feelings of gratitude: a mechanism for consumer reciprocity", European Sport Management Quarterly, Vol. 18 No. 3, pp. 307-329.

Kozinets, R.V. (2015), Netnography, Sage, London.

Kwon, E., Ratneshwar, S. and Kim, E. (2016), "Brand image congruence through sponsorship of sporting events: a reinquiry of Gwinner and Eaton (1999)", Journal of Advertising, Vol. 45 No. 1, pp. 130-138.

Lamont, M., Hing, N. and Gainsbury, S. (2011), "Gambling on sport sponsorship: a conceptual framework for research and regulatory review", Sport Management Review, Vol. 14 No. 3, pp. 246-257.

Lincoln, Y.S. and Guba, E.G. (1982), Establishing Dependability and Confirmability in Naturalistic Inquiry Through an Audit, paper presented at the annual meeting of the American Educational Research Association, New York, NY.

Lough, N.L. and Irwin, R.L. (2001), “A comparative analysis of sponsorship objectives for US women's sport and traditional sport sponsorship”, Sport Marketing Quarterly, Vol. 10 No. 4, pp. 202-211.

McDaniel, S.R. (1999), "An investigation of match-up effects in sport sponsorship advertising: the implications of consumer advertising schemas", Psychology and Marketing, Vol. 16 No. 2, pp. 163-184.

McDonald, C. (1991), "Sponsorship and the image of the sponsor", European Journal of Marketing, Vol. 25 No. 11, pp. 31-38.

Madrigal, R. (2000), "The influence of social alliances with sports teams on intentions to purchase corporate sponsors' products", Journal of Advertising, Vol. 29 No. 4, pp. 13-24.

Mazodier, M. and Merunka, D. (2012), "Achieving brand loyalty through sponsorship: the role of fit and self-congruity”, Journal of the Academy of Marketing Science, Vol. 40 No. 6, pp. 807-820.

Medway, D., Gillooly, L. and Warnaby, G. (2018), "Scalar tensions in urban toponymic inscription: the corporate (re)naming of football stadia”, Urban Geography, Vol. 40 No. 6, pp. 784-804.

Meenaghan, T. (1991), "Sponsorship: legitimising the medium”, European Journal of Marketing, Vol. 25 No. 11 , pp. 5-10.

Meenaghan, T. (2001), "Understanding sponsorship effects", Psychology and Marketing, Vol. 18 No. 2, pp. $95-122$.

Morales, A.C. (2005), “Giving firms an 'E' for effort: consumer responses to high-effort firms”, Journal of Consumer Research, Vol. 31 No. 4, pp. 806-812.

Murtagh, L. (2007), "Implementing a critically quasi-ethnographic approach", The Qualitative Report, Vol. 12 No. 2, pp. 193-215.

Nakazawa, M., Yoshida, M. and Gordon, B.S. (2016), "Antecedents and consequences of sponsorstadium fit: empirical evidence from a non-historic stadium context in Japan”, Sport, Business and Management: An International Journal, Vol. 6 No. 4, pp. 407-423.

Nufer, G. and Bühler, A. (2010), "How effective is the sponsorship of global sports events? A comparison of the FIFA world cups in 2006 and 1998", International Journal of Sports Marketing and Sponsorship, Vol. 11 No. 4, pp. 33-49.

Olson, E.L. and Thjømøe, H.M. (2011), "Explaining and articulating the fit construct in sponsorship", Journal of Advertising, Vol. 40 No. 1, pp. 57-70. 
Palmatier, R.W., Jarvis, C.B., Bechkoff, J.R. and Kardes, F.R. (2009), "The role of customer gratitude in relationship marketing", Journal of Marketing, Vol. 73 No. 5, pp. 1-18.

Petrovici, D., Shan, Y., Gorton, M. and Ford, J. (2015), "Patriot games? Determinants of responses to Chinese and foreign sponsors of the Beijing Olympics", Journal of Business Research, Vol. 68 No. 6, pp. 1324-1331.

Plewa, C. and Quester, P.G. (2011), "Sponsorship and CSR: is there a link? A conceptual framework", International Journal of Sports Marketing and Sponsorship, Vol. 12 No. 4, pp. 22-38.

Polit, D.F. and Beck, C.T. (2010), "Generalization in quantitative and qualitative research: myths and strategies”, International Journal of Nursing Studies, Vol. 47 No. 11, pp. 1451-1458.

Reysen, S., Snider, J.S. and Branscombe, N.R. (2012), "Corporate renaming of stadiums, team identification, and threat to distinctiveness", Journal of Sport Management, Vol. 26 No. 4, pp. 350-357.

Rifon, N.J., Choi, S.M., Trimble, C.S. and Li, H. (2004), "Congruence effects in sponsorship: the mediating role of sponsor credibility and consumer attributions of sponsor motive", Journal of Advertising, Vol. 33 No. 1, pp. 30-42.

Ross, S.D., James, J.D. and Vargas, P. (2006), "Development of a scale to measure team brand associations in professional sport", Journal of Sport Management, Vol. 20 No. 2, pp. 260-279.

Roy, D.P. and Cornwell, T.B. (1999), "Managers' use of sponsorship in building brands: service and product firms contrasted", International Journal of Sports Marketing and Sponsorship, Vol. 1 No. 4, pp. 33-48.

Roy, D.P. and Cornwell, T.B. (2003), "Brand equity's influence on responses to event sponsorships", Journal of Product and Brand Management, Vol. 12 No. 6, pp. 377-393.

Ruth, J.A. and Simonin, B.L. (2003), "Brought to you by brand a and brand B' investigating multiple sponsors' influence on consumers' attitudes toward sponsored events", Journal of Advertising, Vol. 32 No. 3, pp. 19-30.

Simmons, C.J. and Becker-Olsen, K.L. (2006), "Achieving marketing objectives through social sponsorships", Journal of Marketing, Vol. 70 No. 4, pp. 154-169.

Skard, S. and Thorbjornsen, H. (2017), "Closed-ended and open-ended fit articulation: communication strategies for incongruent sponsorships", European Journal of Marketing, Vol. 51 Nos 7/8, pp. 1414-1439.

Smith, G. (2004), "Brand image transfer through sponsorship: a consumer learning perspective", Journal of Marketing Management, Vol. 20 Nos 3/4, pp. 457-474.

Snyder, C.R., Lassegard, M. and Ford, C.E. (1986), "Distancing after group success and failure: basking in reflected glory and cutting off reflected failure", Journal of Personality and Social Psychology, Vol. 51 No. 2, pp. 382-388.

Speed, R. and Thompson, P. (2000), "Determinants of sports sponsorship response", Journal of the Academy of Marketing Science, Vol. 28 No. 2, pp. 226-238.

Stake, R.E. (2005), Multiple Case Study Analysis, Guilford Press, New York, NY.

Statista (2017), "Statistics and facts on sports betting", available at: www.statista.com/topics/1740/ sports-betting/ (accessed 10 March 2017).

Tajfel, H. (1974), "Social identity and intergroup behaviour”, Social Science Information), Vol. 13 No. 2, pp. 65-93.

Tajfel, H. (1981), Human Groups and Social Categories: Studies in Social Psychology, Cambridge University Press, Cambridge.

Tajfel, H. (1982), "Social psychology of intergroup relations", Annual Review of Psychology, Vol. 33 No.1, pp. 1-39.

Tajfel, H. and Turner, J.C. (1979), "An integrative theory of intergroup conflict”, in Austin, W.G. and Worchel, S. (Eds), The Social Psychology of Intergroup Relations, Brooks-Cole, Monterey, CA, pp. 33- 47. 
Taylor, D. (2011), "Manchester city bank record $£ 400 \mathrm{~m}$ sponsorship deal with etihad airways", available at: www.theguardian.com/football/2011/jul/08/manchester-city-deal-etihad-airways (accessed 23 February 2017).

Tsang, J.A. (2007), "Gratitude for small and large favors: a behavioral test", The Journal of Positive Psychology, Vol. 2 No. 3, pp. 157-167.

Vuolteenaho, J., Wolny, M., Puzey, G. (2018), “This venue is brought to you by ...'? the diffusion of sports and entertainment facility name sponsorship in urban Europe", Urban Geography, pp. 1-22, doi: 10.1080/02723638.2018.1446586.

Wann, D.L. and Branscombe, N.R. (1995), "Influence of identification with a sports team on objective knowledge and subjective beliefs", International Journal of Sport Psychology, Vol. 26 No. 4, pp. 551-567.

Weeks, C.S., Cornwell, T.B. and Drennan, J.C. (2008), "Leveraging sponsorships on the internet: activation, congruence, and articulation", Psychology and Marketing, Vol. 25 No. 7, pp. 637-654.

Woisetschläger, D.M., Backhaus, C. and Cornwell, T.B. (2017), "Inferring corporate motives: how deal characteristics shape sponsorship perceptions", Journal of Marketing, Vol. 81 No. 5, pp. 121-141.

Woisetschläger, D., Eiting, A., Haselhoff, V. and Michaelis, M. (2010), "Determinants and consequences of sponsorship fit: a study of fan perceptions", Journal of Sponsorship, Vol. 3 No. 2, pp. 169-180.

Woisetschläger, D.M. and Haselhoff, V.J. (2009), “The name remains the same for fans' - why fans oppose naming right sponsorships", in McGill, A. and Shavitt, S. (Eds), NA - Advances in Consumer Research Volume, 36, Association for Consumer Research, Duluth, MN, pp. 775-776.

Woisetschläger, D.M., Haselhoff, V.J. and Backhaus, C. (2014), "Fans' resistance to naming right sponsorships: why stadium names remain the same for fans", European Journal of Marketing, Vol. 48 Nos 7/8, pp. 1487-1510.

\section{Corresponding author}

Leah Gillooly can be contacted at: 1.gillooly@mmu.ac.uk

For instructions on how to order reprints of this article, please visit our website: 